\begin{tabular}{|c|c|c|}
\hline & International Journal of Current Research in & \\
\hline & Biosciences and Plant Biology & \\
\hline $\begin{array}{l}\text { EXELLEN } \\
\text { PUBLISHERS }\end{array}$ & $\begin{array}{c}\text { ISSN: 2349-8080 (Online) } \bullet \text { Volume } 3 \bullet \text { Number } 5 \text { (May-2016) } \\
\text { Journal homepage: } \underline{w w . i j c r b p . c o m}\end{array}$ & \\
\hline
\end{tabular}

\title{
Farming Quotient (FQ) or Framing Intelligence (FI) and Its Relevance in India
}

\author{
Manmohan J. R. Dobriyal ${ }^{1}$ and Arvind Bijalwan²* \\ ${ }^{1}$ Department of Silviculture and Agroforestry, College of Forestry (ACHF), Navsari Agricultural University, \\ Navsari- 396 45o, Gujarat, India \\ ${ }_{2}^{2}$ Indian Institute of Forest Management, P.O.-357, Nehru Nagar, Bhopal-462 oo3, Madhya Pradesh, India
}

*Corresponding author.

\begin{abstract}
A bstract
Farming Quotient (FQ) or Framing Intelligence (FI) is a new term deals the information and warmth of people to the farm community and the perception of people to the farmers. After globalization, the scenario of India farming has changed, which kept on accelerating in good pace with green revolution phenomenon. The FQ of the common Indian people is not as intense as the social and political hype is created in India. FQ is not just academic aptitude of society about farming but in real sense it is the awareness and deep feeling towards the farming community and their role in grass root level to build the nation.
\end{abstract}

\section{Article Info}

Accepted: 05 April 2016

Available Online: 06 May 2016

Keywords

Agriculture

Farming community

Farming quotient

\section{Introduction}

The Farming Quotient (FQ) or Framing Intelligence (FI) can be explained as a basic tool to assess the knowledge and affection of people toward the farming and how they feel for farmers' life style and status. Farming generally refers to be any activities carried out on farmland by a person such as agriculture, horticulture, animal husbandry, fisheries and agroforestry, etc. If we go back to history, there were only two major farming activities as agriculture and animal husbandry however, as time elapsed, the dimension of faming has also linked to agroprocessing, value addition and cooperative marketing of agricultural products etc. In India, where farming based industrialization took momentum very late, and even today farmers could not change their mindset and they still deeply attached with framing culture, works, emotion and tradition.

India is an agrarian country, where about $70 \%$ of Indian population directly or indirectly is depending on farming but decline in agriculture contribution in GDP from 50\% in 1951 to agriculture and allied sectors like forestry and fisheries accounted for $13.7 \%$ of the GDP (gross domestic product) in 2013 (Anon, 2015; https://en.wikipedia.org/wiki/Agriculture_in_India).

Today, India ranks second worldwide in farm output. The mindset of Indian people was to express themselves as member of farm community was very common. However, after 1996 (post globalization period), the scenario of India farming has changed, which kept on accelerating in good pace with green revolution phenomenon. The globalization resulted to more and more people from the rural community started migrating to urban areas in search of new jobs as farming became costly affairs due to shortage of input supply and infrastructure in rural areas. Though, the situation with regards to infrastructures and farming inputs has improved yet nature's vagaries (drought, flood, and storm) still pose threats to poor farmers to leave their fields. The fact is that even after certain good schemes like crop insurance, farmers are not willing to return to 
their respective villages. Therefore, the FQ of the common Indian people is not as intense as the social and political hype is created in India.

\section{Farming Quotient (FQ)}

Now, FQ has important dimension of sensibility and emotional attachment with farming and the composite index of FQ is able to assess the individual or group of people liking farming as well as knowledge about agricultural activities. In India "Gram Swaraj" concept is very old which envisages that everything can be produced within the farm or village boundaries and it can be a self sufficient unit. The philosophy behind this concept is emerged in green cycling of natural resources and utilization of village resources. Moreover, the Gandhian philosophy in India during freedom movement was to discard the foreign goods and use Swedeshi was a symbolic to a self reliant nation. The traditional knowledge and intellectual property terms though coined later but advocates the role indigenous traditional knowledge (ITK) of Indian people for framing and related activities in development of modern society. This traditional farming knowledge blends with modern agriculture sown the seeds of green revolution but in pace of intensive agriculture we left behind the legacy of traditional farming concept. The High FQ of the agrarian communities is more sensible and affectionate towards the farming besides connecting the occupation with tradition, culture, ethos and well being of the society.

\section{FQ - Present scenario}

The modern agricultural science has developed many folds but remain more to academic spheres and laboratories without realizing the on practical field problems and associated factors of Indian farmers and farming. In present days India has the largest network of National Agricultural Research and Education Systems (NARES) in the world with more than 100 institutes under ICAR (Indian council for Agriculture Research) along with 60 to 70 agricultural and veterinary Universities, extensive network of KVKs (Kirshi Vigayna Kendras) and of course respective departments on agriculture, horticulture and animal husbandry. Furthermore, for more specific inputs we have VCI (Veterinary council of India) and ICFRE (Indian council for Forestry Research and Education) dealing with veterinary and forestry issues respectively. Even after about 70 years of independence with so much institutional advancement we fail to reach out to farming community to solve farming issues as a result alarming number of farmers committing suicide in the country day by day. This reflects the sensibility of Indian people towards farm community. Despite the fact that the country vested with number of agro-climatic and agroecological regions from alpine to coastal and arid to high rainfall region could not make its much impact on agro-biodiversity. These natural gifts of unique geography explored by our ancestors and preserved, however, we are still not aware of traditional farming knowledge and their parlance in this field. The FQ, preserve in the other part of globe cannot be compared with Indian context as Indian are rationally more devoted farming practice by soul rather science.

Today the gloomy pictures of Indian youngsters even from rural areas not wish to educate them in agricultural sciences and those are educating in agricultural sciences not wish to go to agriculture fields. This paradox of Indian NARES required a serious thinking for sensibly and accordingly plan scientific improvement of Indian farming. Today, even a farmer is not wishes to continue farming to their next generation due to poor social recognition, low income, and threat from climatic vagaries etc. Now the question arises how we can increase the Farming Quotient of common Indian? In the olden days, people from urban areas used to visit their native villages and kept in touch with farming but in recent past this trends has been radically declined. The busy lifestyle of cities, pressure of profession and eager for making money forced common people to alienate from their roots even in the same generation. It has been observed, that the migration for job in cities was previously a seasonal practice and people remain attached to villages but now it has become a permanent features. This trend is not only posing threats to farming in large but also putting pressures on urban areas. If we see the scenario of states like HP. UK, North East, Rajasthan, UP, Bihar, etc., a lot of people migration leaving abandoned villages and farming lands without tillage. Though the infra structure has been improved in rural areas compared to earlier but still people are not willing their next generation to stay in villages due to low FQ. Therefore, there is a need to strongly link FQ with present generation to the next generation. If this trend continue in society it will be difficult to feed such a large country without farming.

\section{Will it change or we need to change?}

It is well known fact that, farming without attaching yourself to the farm will not yield any results. The metro life of fast food, hotel foods and readymade eateries had 
vanish the charm of even cooking in home than how far retaining the farming practices or even knowing about the crops, their nutritional value etc. The days will not be far when kids will ask is apple come from Adam's apple and not from apple tree grown in orchard. It true that, we can educate the people about the farming and farm produce but at the same time sensitizing toward farmers will make our FQ stronger. It is also a question of our sensibility and emotional feeling about farmers and farming who grows the crops and how much he take care till the final harvest of crop and ultimately how much share he is getting from your paid price. There are many questions to understand the complex social, economical and ecological aspects of farming but if we feel a part of it then only we will get answers of our late Prime
Minister Lal Bhadur Shatri Praising the farmers like soldiers from whom we are emotionally and nationally attached as "Jai Jawan, Jai Kisan". Therefore, FQ is not just academic intelligence of people about farming but in real sense it is the sensibility and deep feeling towards the farming community and their role in grass root level to build the nation.

\section{References}

Anon, 2015. Agricultural Statistics at a Glance. Ministry of Agriculture, Government of India 2015, Oxford University press.

https://en.wikipedia.org/wiki/Agriculture_in_India

\section{How to cite this article:}

Dobriyal, M. J. R., Bijalwan, A., 2016. Farming Quotient (FQ) or Framing Intelligence (FI) and its relevance in India. Int. J. Curr. Res. Biosci. Plant Biol. 3(5), 144-146.

doi: http://dx.doi.org/10.20546/ijcrbp.2016.305.022 